\title{
Effect of Restricted Feeding and Monopropylene Glycol Postpartum on Metabolic Hormones and Postpartum Anestrus in Grazing Dairy Heifers
}

\author{
L. M. Chagas, ${ }^{*}$ P. J. S. Gore, ${ }^{*}$ G. Graham, $†$ K. A. Macdonald, ${ }^{, 1}$ and D. Blache $†$ \\ *DairyNZ, Private Bag 3221, Hamilton, New Zealand \\ †The University of Western Australia, 37 Stirling Highway, Crawley, 6009, Australia
}

\section{ABSTRACT}

This study was designed to determine the effects of feed restriction and monopropylene glycol (MPG) supplementation on the reproductive, milk production, and somatotropic axes in dairy heifers postpartum. At calving, 49 Holstein-Friesian heifers were allowed either unrestricted (UNR; $\mathrm{n}=18$ ) or restricted access to pasture with (RES+MPG; $\mathrm{n}=13$ ) or without (RES; $\mathrm{n}=18$ ) MPG supplementation (250 mL drenched twice daily for $150 \mathrm{~d}$ ). The average body condition score (BCS) of the heifers was $5.3 \pm 0.2$ on a scale from 1 to 10 (where $1=$ emaciated and $10=$ obese). Body condition score and body weight were similar among the groups at calving and decreased after calving for all groups. However, body weight loss was around $10 \%$ greater for the RES and RES+MPG groups from wk 3 to 12 compared with UNR group. The length of the postpartum anestrous interval was similar for all groups $(47,51$, and 45 $\pm 5 \mathrm{~d}$ for the UNR, RES, and RES+MPG, respectively). Average milk production, protein, fat, and lactose yields during the first $12 \mathrm{wk}$ postpartum were greater in the UNR group than in the RES and RES+MPG groups. Feed restriction affected plasma concentrations of insulin, with lower concentrations in the RES group compared with the UNR group. There were no differences in plasma concentrations of insulin between the RES+MPG group and the UNR or RES groups. An effect of feed restriction was observed on insulin-like growth factor-I concentrations and also a treatment by time interaction with a changing pattern through time as concentrations in the UNR group increased relative to the RES and RES+MPG groups. There were no differences in growth hormone concentrations among the groups. Glucose concentrations were lower in the RES group when compared with RES+MPG and UNR groups and this difference lessened over time. Plasma

Received May 3, 2007.

Accepted January 13, 2008.

${ }^{1}$ Corresponding author: kevin.macdonald@dairyNZ.co.nz concentrations of nonesterified fatty acids were greater in the RES group compared with the RES+MPG and UNR groups. Leptin concentrations in the UNR group were greater than in the RES and RES+MPG groups. Hepatic growth hormone receptor 1A, total growth hormone receptor, and insulin-like growth factor-I relative mRNA expressions decreased postpartum with no effect of feed restriction, MPG supplementation, or interaction between time and treatment. During a challenge with MPG, insulin secretion was stimulated but no effect on postpartum anestrous interval in the treatment groups was observed. It was concluded that restricted pasture availability postpartum in dairy heifers calving in optimal BCS had no effect on the postpartum anestrous interval. It did however decrease milk production; thus, we can infer that monopropylene glycol supplementation does not act to prevent loss of milk yield.

Key words: postpartum anestrus, monopropylene glycol, metabolic challenge, dairy heifer

\section{INTRODUCTION}

For a high reproductive efficiency an early resumption of estrous cycle postpartum is important for both year-round and seasonal calving systems. In a seasonal pasture-based system, cows need to conceive by $83 \mathrm{~d}$ after calving on average (assuming the gestation length is $282 \mathrm{~d}$ ) to maintain a 365-d calving interval. Delays in the initiation of ovulation are associated with reduced conception rates and pregnancy rates and increased intervals from calving to conception. For these reasons, a herd with a large percentage of cows experiencing a prolonged postpartum anestrous interval (PPAI) would experience a major loss of productivity with cows calving late and having fewer days in milk in the following season. During the postpartum period, dairy cows experience a prolonged period of negative energy balance (Bauman and Currie, 1980). In addition, in New Zealand's pasture feeding system, climatic variables can affect feed availability in spring, and nutrient availability can be restricted during the postpartum period. The recovery toward positive energy balance is associ- 
ated with the resumption of reproductive cyclicity (Butler et al., 1981), which suggests that by increasing the influx of energy-rich nutrients the fertility of dairy herds may be improved.

Heifers calving in low BCS (calving at BCS of 4.1 for a optimal target of 5.5 at calving, scale from 1 to 10) and receiving twice-daily postpartum administration of monopropylene glycol (MPG) had decreased plasma concentrations of NEFA, increased LH pulse frequency, and shortened PPAI (Chagas et al., 2007). This suggests that a glucose precursor such as MPG has the capacity to compensate for the extra energy requirements of reproductive function during the early postpartum period, or that the effect of MPG on the length of the postpartum anovulatory period may have been elicited through the increase in LH pulsatility (Chagas et al., 2007).

How the amount of body reserves is sensed and the mechanisms by which MPG stimulates the reproductive axis are not fully understood. One hypothesis is that MPG action occurs through changes in the somatotrophic axis. During early lactation, the somatotrophic axis, consisting of growth hormone (GH), GH receptor (GHR), IGF-I, and IGF-binding proteins, controls nutrient partitioning (McGuire et al., 1992; Etherton and Bauman, 1998). Liver GHR and blood IGF-I concentrations rapidly decrease shortly after calving (Radcliff et al., 2003). The decrease in blood IGF-I concentrations reduces the level of negative feedback on GH secretion, resulting in an increase in blood GH concentrations. The increase in GH concentrations drives nutrient partitioning in favor of milk production during early lactation, resulting in body tissue mobilization and the release of NEFA into the blood stream (Emery et al., 1964). Administration of MPG has been shown to be effective in reducing plasma NEFA and increasing glucose and insulin concentrations (Formigoni et al., 1996; Miyoshi et al., 2001), helping to lessen some of the effects of prolonged postpartum NEB (Bertics et al., 1992). These studies suggest that MPG could reduce PPAI by increasing the availability of nutrients for reproductive function and by supplying specific nutrients that enhance hormonal systems known to trigger ovulation in cattle (e.g., LH and insulin). Whether the MPG effect results from an increase in glucose concentrations and an associated stimulation of insulin still needs to be determined. One possibility is that MPG stimulates insulin secretion, which acts directly on the ovary. Alternatively, insulin increases hepatic GHR thereby stimulating hepatic IGF-I secretion and ovarian development. The objective of this study was to determine the effects of feed restriction and MPG supplementation on the reproductive and somatotrophic axes and milk production in pasture-fed dairy heifers postpartum.

\section{MATERIALS AND METHODS}

\section{Experimental Design and Treatments}

Forty-nine Holstein-Friesian heifers (2 yr old) that had conceived during a 2 -wk interval following AI were used. Pasture allowances were managed during the last 5 mo of gestation such that at parturition, the heifers average BCS was $5.3 \pm 0.2$ on a 1 to 10 scale $(1=$ emaciated and $10=$ obese). In New Zealand the ideal calving BCS for a 2-yr-old heifer is 5.5 (Macdonald and Roche, 2004); BCS of 5.5 at calving for heifers is labeled as "optimal" BCS. Roche et al. (2004) compared the New Zealand 10-point scale with the United States (5-point scale), and presented a regression equation to allow easy conversion between the systems (US $=1.5+0.32$ $\mathrm{NZ)}$. Allocation to treatments was random, with balancing for BW and genetic merit for milk production. Animals were weighed and BCS assessed weekly. At calving, the heifers were allowed either unrestricted (UNR; $\mathrm{n}=18$ ) or restricted access to pasture with (RES+MPG; $\mathrm{n}=13)$ or without $(\mathbf{R E S} ; \mathrm{n}=18)$ MPG supplementation. Monopropylene glycol (Agri-Feeds, Mount Maunganui, New Zealand) was administered as an oral drench (250 $\mathrm{mL}$ ) twice a day (before milking) from calving until the end of artificial breeding (approximately $150 \mathrm{~d}$ ). The restriction in pasture intake was equivalent to typical DMI in a commercial New Zealand dairy farm. The average day of calving was July 9 ( \pm 6 d), July $11( \pm 10$ d), and July 11 ( \pm 8 d) for UNR, RES+MPG, and RES, respectively.

This experiment was conducted at DairyNZ Lye Farm, Hamilton, New Zealand $\left(37^{\circ} 46^{\prime} \mathrm{S} 175^{\circ} 18^{\prime} \mathrm{E}\right)$. The Ruakura Animal Ethics Committee, Hamilton, New Zealand, approved all procedures.

\section{Grazing Management}

Pasture offered was predominantly perennial ryegrass (Lolium perenne L.) and white clover (Trifolium repens), with $<20 \%$ weeds and other grasses (Dactylis glomerata, Poa spp.) on a DM basis. Each treatment group grazed separately in 0.25 -ha paddocks and a different pasture area was allocated to adjust stocking density (animals/ha per d), thereby achieving a range of DMI values. Low pasture residuals after grazing can be used to restrict DMI in grazing experiments, because dairy stock have difficulty in grazing pasture to ground level (Roche et al., 2005). Offering different grazing area allocations facilitated the achievement of different cow DMI without confounding factors such as time at pasture or climatic influences.

Before calving, all heifers were grazed together and fresh pasture was allocated each morning. Pasture allocations were assessed visually and assessments were 
calibrated weekly through cutting a range of pasture yields representative of pre- and postgrazing yields (Thom et al., 1986). The DMI of each treatment was calculated daily from pregrazing and postgrazing pasture mass (Roche et al., 1996).

After calving, the UNR and RES treatment groups were grazed separately. The heifers were allocated fresh pasture following each milking. Average pregrazing pasture mass was similar for each treatment group $2,669 \pm 456$ and $2,552 \pm 485 \mathrm{~kg}$ of DM/ha for UNR and RES groups, respectively. Average postgrazing residual pasture mass was $1,713 \pm 259$ and $1,154 \pm 249 \mathrm{~kg}$ of $\mathrm{DM} /$ ha for UNR and RES groups, respectively. The RES treatment groups were offered $73 \%$ of the allowance of the UNR treatment group. The RES group was allocated $77 \mathrm{~m}^{2} / \mathrm{cow}$ and the UNR $106 \mathrm{~m}^{2} / \mathrm{cow}$, which allowed pasture DMI of $14.3 \pm 1.60$ and $11.2 \pm 1.36 \mathrm{~kg}$ of $\mathrm{DM} /$ cow for UNR and RES groups, respectively.

\section{Blood Sampling}

Coccygeal venipuncture was used to collect blood samples weekly from $-1 \mathrm{wk}$ prepartum to $12 \mathrm{wk}$ postpartum to measure concentrations of NEFA, glucose, insulin, IGF-1, GH, and leptin. Blood samples were taken in the morning (approximately $0730 \mathrm{~h}$ ) pre- and postpartum before new pasture was offered and before milking postpartum.

All blood samples were collected into $10-\mathrm{mL}$ vacutainer tubes containing sodium heparin, and immediately placed on ice. Blood samples were centrifuged at $1,120 \times g$ for $12 \mathrm{~min}$, within $1 \mathrm{~h}$ of collection. Aliquots of plasma were stored at $-20^{\circ} \mathrm{C}$ until assayed.

\section{Interval to First Ovulation and Milk Production Measurements}

Progesterone concentrations were measured twice per week in fresh whole milk samples collected before the start of each milking. The PPAI was defined as the interval from calving to the first of 2 consecutive sampling days that progesterone concentrations in milk were greater than $3 \mathrm{ng} / \mathrm{mL}$, indicating ovulation (Chagas et al., 2006).

Weekly milk yields were measured throughout lactation using in-line milk meters (TruTest, Auckland, New Zealand) and subsamples were taken to measure protein, fat and lactose concentrations (MilkoScan FT120, Foss, Hillerød, Denmark).

\section{Effect of MPG Challenge on Insulin and Metabolites}

At 2 wk postpartum an MPG challenge was performed on a subsample of cows from RES+MPG and
RES groups. Jugular catheters were inserted under local anesthesia to facilitate frequent blood collection. On the following morning and after overnight fasting, heifers in the RES+MPG group $(\mathrm{n}=10)$ were drenched with $250 \mathrm{~mL}$ of MPG and those in the RES group ( $\mathrm{n}=$ 10) were drenched with water. Samples were collected at $0,5,10,15,20,30,40,60,90,120$, and $240 \mathrm{~min}$ relative to the time of drenching (MPG or water). Heifers in the RES+MPG group did not receive their daily dose of MPG before the challenge. The MPG challenge dose was similar to the daily dose used in the trial to determine the effect of MPG on insulin, glucose and NEFA secretion.

\section{Hormone and Metabolite Assays}

Plasma glucose was measured by the hexakinase colorimetric method of Schmidt (1961) using a Hitachi 717 analyzer (Roche, Basel, Switzerland) at $30^{\circ} \mathrm{C}$ by Gribbles Ltd. (Hamilton, New Zealand). Plasma NEFA was measured by using a commercially available enzymatic-colorimetric kit (NEFA-C, Wako Diagnostics, Richmond, VA). The intra- and interassay coefficients of variation $(\mathbf{C V})$ for both assays were 2 and $3 \%$, respectively.

Insulin was measured in duplicate using a doubleantibody RIA (Hales and Randle, 1963) validated for bovine plasma (Chagas et al., 2007). The intra- and interassay CV were 2 and 3\%, respectively. The limit of detection of the assay was $0.89 \mu \mathrm{U} / \mathrm{mL}$.

Leptin was measured in duplicate using a doubleantibody RIA (Blache et al., 2000). The limit of detection of the assay was $0.1 \mathrm{ng} / \mathrm{mL}$. The intra- and interassay CV were 4.8 and $5.7 \%$, respectively.

Plasma IGF-I was assayed in duplicate by doubleantibody RIA (Gluckman et al., 1983) with human recombinant IGF-I (ARM4050, Amersham-Pharmacia Biotech, Buckinghamshire, UK) and anti-human IGF-I antiserum (AFP4892898, National Hormone and Pituitary Program of the National Institute of Diabetes and Digestive and Kidney Diseases, NHPP-NIDDK; final dilution; 1:360,000) following acid-ethanol extraction and cryoprecipitation (Breier and Gluckman, 1991). The assay method has previously been validated for bovine plasma samples (Chagas et al., 2007). The intraand interassay CV were 5.3 and $5.7 \%$, respectively. The limit of detection of the assay was $1 \mathrm{ng} / \mathrm{mL}$.

Plasma samples were assayed for GH in duplicate by double-antibody RIA (Downing et al., 1995) with ovine GH (NIDDK-I-5, NHPP-NIDDK) and anti-ovine GH antiserum (NIDDK-anti-oGH-3, NHPP-NIDDK; final dilution 1:300,000) following acid-ethanol extraction and cryoprecipitation (Breier and Gluckman, 1991). Validation for bovine plasma was as previously reported (Cha- 
gas et al., 2007). The intra- and interassay CV were 6.9 and $8.2 \%$, respectively. The assay detection limit was $0.06 \mathrm{ng} / \mathrm{mL}$.

The concentration of progesterone in milk was measured using an ELISA kit (Ridgeway Sciences, Gloucestershire, UK), validated for use in cattle (Sauer et al., 1986). Intra- and interassay CV were 6.1 and $8.6 \%$ for standard concentrations of $4.4,3.0$, and $0.4 \mathrm{ng} / \mathrm{mL}$, respectively.

\section{Liver Biopsies}

On wk $-1,1,4,8$, and 12 relative to calving, a liver sample was collected from a subset of animals $(n=6$ per group) to determine the mRNA expression of GHR1a, GHRtotal, and IGF-I.

For liver tissue collection, a region on the right side of the animal, through the second to last intercostal space (at least $10 \mathrm{~cm}$ radius), was clipped and cleansed with povidone iodine soap and iodine tincture (10\% povidone iodine in $70 \%$ alcohol). Local anesthesia $(10 \mathrm{~mL}$ of $2 \%$ lidnocaine hydrochloride solution) was then administered subcutaneously at the site of incision and a scalpel blade was used to penetrate the skin. Samples (approximately $200 \mathrm{mg}$ ) were collected with a custommade liver biopsy needle $(20 \mathrm{~cm}$ length, $10 \mathrm{Fr}$ gauge diameter) and immediately snap-frozen in liquid nitrogen before being stored at $-80^{\circ} \mathrm{C}$ until RNA extraction.

\section{RNA Extraction}

Total RNA was isolated from liver tissue $(\leq 100 \mathrm{mg})$ using a method based on that developed by Chomczynski and Sacchi (1987), and a commercial extraction buffer, Trizol (Invitrogen Australia Pty Ltd., Mount Waverley, Victoria, Australia). Samples were transferred into a lysing matrix D tube (Qbiogene, MP Biomedicals, Australasia, Seven Hills, NSW, Australia) containing $1 \mathrm{~mL}$ of Trizol and homogenized using a fastprep instrument (Qbiogene, MP Biomedicals) at speed 5.5 for $30 \mathrm{~s}$. The Trizol extraction then proceeded according to the manufacturer' s instructions with the RNA pellet obtained dissolved in a final volume of 50 $\mu \mathrm{L}$ of RNase-free water, with heating at 55 to $60^{\circ} \mathrm{C}$ for 10 min to assist the complete dissolution of RNA. The concentration of RNA was determined spectrophotometrically. The quality of RNA was determined by gel electrophoresis ( $100 \mathrm{~V}$ for $30 \mathrm{~min}$ with recirculation of buffer) of $2.5 \mu \mathrm{g}$ of RNA on a $10 \mathrm{mM}$ phosphate buffer ( $\mathrm{pH} 6.8$, with $0.1 \mathrm{mg} / \mathrm{L}$ of ethidium bromide), $1.4 \%$ agarose gel.

\section{cDNA Preparation}

The cDNA was prepared from $2 \mu \mathrm{g}$ of total RNA using the SuperScript III Reverse Transcriptase first-strand
cDNA synthesis kit (Invitrogen Australia Pty Ltd.) according to the manufacturer's directions.

\section{Real-Time Reverse Transcription-PCR}

Real-time reverse transcription (RT)-PCR was performed on a Corbett Rotorgene 3000 (Corbett Life Science, Sydney, Australia). Primers, dual-labeled fluorescent probes, and standards were synthesized for cattle GHR1a, GHRtotal, and IGF1 (Sigma-Proligo Australia, Lismore, New South Wales, Australia). The primers used have previously been cited by Radcliff et al. (2003). New probes were designed; GHR1A probe: 5'(6-Fam)TGCCAGAGATCCATACCTGTAGGACCAA GA(Tamra), GHRtotal probe: 5'(6-Fam)ACCTTGGCA GTGGCAGGCTCCA(Tamra), IGF1 probe: 5'(6-Fam)C TTTTATTTCAACAAGCCCACGGGGTATGG(Tamra). The standards used were synthesized to correspond with the region of the gene amplified with these primers sets. The RT-PCR was performed in a final volume of $25 \mu \mathrm{L}$ with the reagent final concentrations as follows: $200 \mathrm{n} M$ probe, $4 \mathrm{mM} \mathrm{MgCl}{ }_{2}$ (Qiagen, Doncaster, Victoria, Australia), $200 \mu M$ deoxynucleoside triphosphates (Invitrogen Australia Pty Ltd.) and $800 \mu M$ for each primer. Hotstar Taq (Qiagen) was used at a concentration of 0.625 units per reaction along with the supplied $10 \times$ buffer. For each sample, $1 \mu \mathrm{L}$ of 1 -in- 5 diluted cDNA was added to the reaction along with sterile water to bring the final volume to $25 \mu \mathrm{L}$. Nutritional treatments are known to influence the expression of many housekeeping genes (Janovick-Guretzky et al., 2007); therefore, a standard curve was used to determine absolute gene expression. Standards were created by serially diluting a synthesized oligo (corresponding to the relevant gene sequence) over the concentration range found in the samples. For each gene the amplification efficiency of the standard used and cDNA from cattle liver was the same, as demonstrated by equivalent slopes on a log scale obtained for all dilutions of standards and an internal reference sample (pool of subset of cDNA samples). No-template controls (water) and the internal reference sample were included in each assay. The standard curve generated was used to determine the absolute concentration $(\mathrm{pg} / \mathrm{mL})$ of each gene in the samples. Values were corrected for the dilution of the cDNA. Because of the large number of samples, multiple real-time reactions were run. To account for any differences between runs, the absolute concentrations determined from the standard curve for each sample were normalized by dividing them by the internal reference sample concentration measured in the same run. This normalization provided expression ratios that were comparable between runs. 

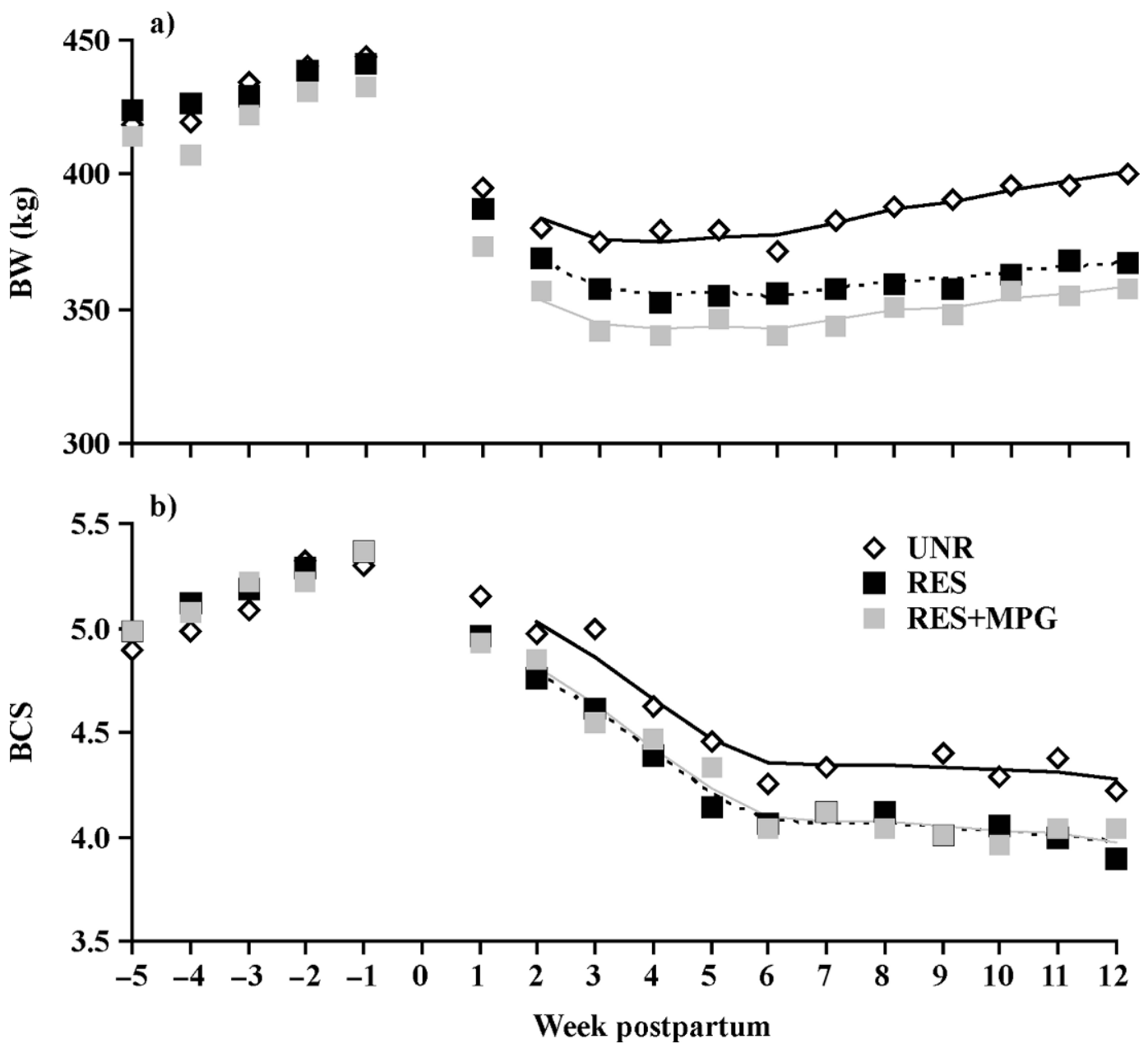

Figure 1. Mean (a) BW and (b) BCS (on a scale from 1 to 10) from 5 wk before until 12 wk after calving. Heifers had unrestricted (UNR) or restricted access to pasture (RES) or restricted access to pasture and supplemented with monopropylene glycol (RES+MPG).

\section{Statistical Analyses}

The milk data for wk 2 to 12 of lactation were analyzed by calculating the average daily milk, protein, fat, lactose, and milk solids (fat plus protein) yields for each cow over time and then analyzing these summary measures using ANOVA. Milk, metabolite, hormone, $\mathrm{BW}$, and BCS data for the first week of lactation were omitted from this analysis because the number of days from calving to the first herd test-date varied among the heifers. For the metabolite, hormone, BW, and BCS data the repeated measurements through time were modeled using spline models within the linear mixed model framework, as described by Verbyla et al. (1999). Treatment, linear trend over time, and their interaction were included as fixed effects and cow, linear trend of time within cow, spline, and the interaction of treatment with spline were included as random effects. Residual maximum likelihood (REML) in GenStat 8 (VSN
International Ltd., Hemel Hempstead, UK) was used to fit these models. Fitted curves and average standard error of the difference between treatments are presented in the figures. Weekly means are presented to illustrate the interactions between time and treatment. For consistency, all metabolite, hormone, BW, and BCS data are presented in this manner. The length of the postpartum anestrous interval was analyzed using the CENSOR procedure in GenStat. Repeated-measures ANOVA was used to analyze the real-time RT-PCR results.

\section{RESULTS}

\section{$B W$ and $B C S$}

Before calving, BW was similar in all groups (means for all $5 \mathrm{wk}$ were $440 \mathrm{~kg}$ in UNR; $429 \mathrm{~kg}$ in RES+MPG, $437 \mathrm{~kg}$ in RES, mean $\pm 16 \mathrm{~kg}$ overall SEM). After calv- 


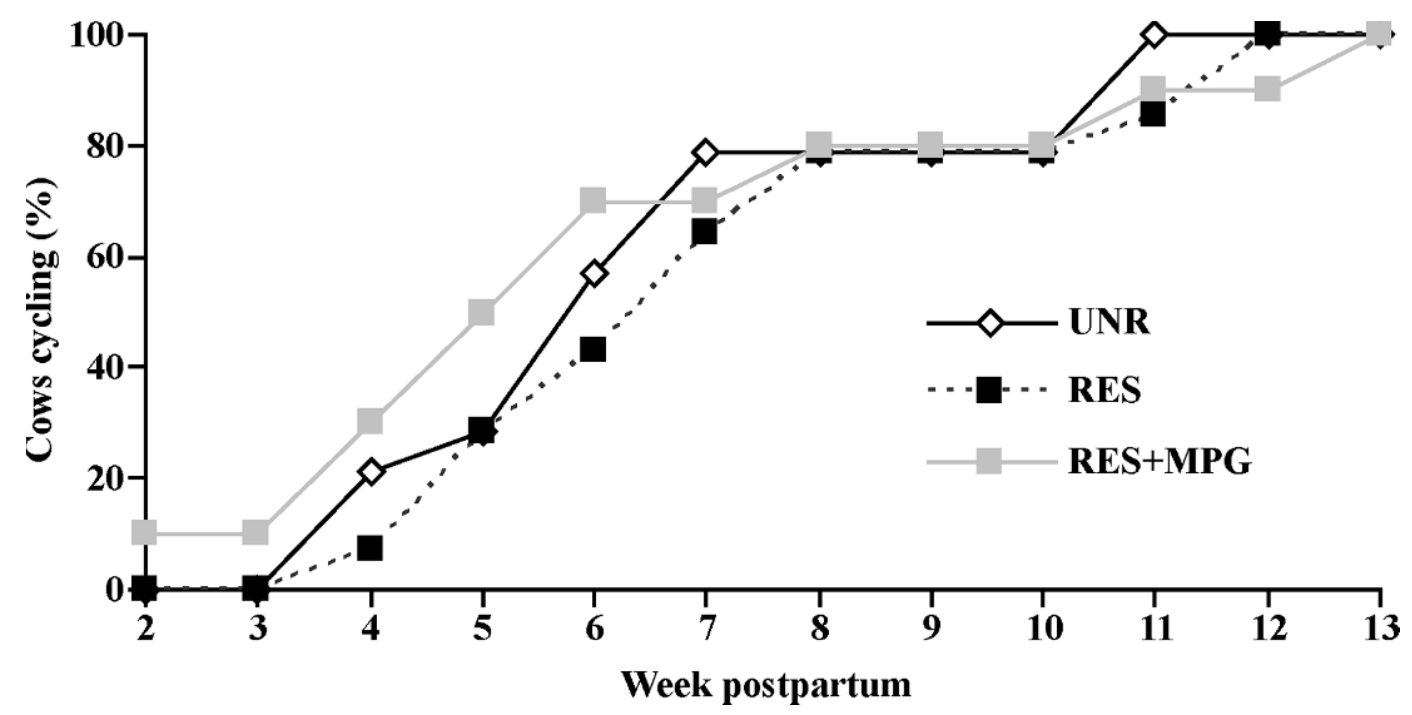

Figure 2. Percentage of heifers cycling during the first $13 \mathrm{wk}$ postpartum. Heifers had unrestricted (UNR) or restricted access to pasture (RES) or restricted access to pasture and supplemented with monopropylene glycol (RES+MPG).

ing, there were no time interactions or treatment effects of restriction and MPG supplementation on BW. Over the first 2 experimental weeks postpartum, BW decreased in all groups; however, BW was around 10\% greater $(P<0.001)$ for the UNR group from wk 3 to 12 compared with the RES and RES+MPG groups (Figure 1 ). At the end of the experimental period, BW was greater $(P<0.001)$ for the UNR group $(399 \mathrm{~kg} \pm 11 \mathrm{~kg})$ for both the RES+MPG (357 kg $\pm 11 \mathrm{~kg})$ and RES (369 $\mathrm{kg} \pm 11 \mathrm{~kg}$ ) groups, but not different between RES+MPG and RES groups $(P=0.29)$.

In the 5 -wk period before calving, the BCS of all heifers were similar (mean for all 5 wk of $5.0 \pm 0.4$ ). At calving, heifers had an average BCS of $5.3 \pm 0.2$. After calving, there was no treatment by time interaction or treatment effect on BCS, but BCS decreased over time in all groups (Figure 1). At the end of the experimental period, BCS of all heifers were similar, with the BCS being $4.25,4.03$, and $3.95 \pm 0.21$ overall SEM for the UNR, RES+MPG, and RES groups, respectively.

\section{Interval to First Ovulation and Milk Production}

The percentage of animals that had ovulated by wk 7 after the mean calving date was similar in all groups (Figure 2). The length of the postpartum anestrous interval was similar for all groups (47, 45, and $51 \pm 5 \mathrm{~d}$ for the UNR, RES+MPG, and RES, respectively).

Mean milksolids (1.28 $\mathrm{kg}$ in UNR, $1.08 \mathrm{~kg}$ in RES+MPG, $1.14 \mathrm{~kg}$ in RES groups \pm 0.04$)$, protein $(0.54$ $\mathrm{kg}$ in UNR, $0.48 \mathrm{~kg}$ in RES+MPG, $0.48 \mathrm{~kg}$ in RES \pm $0.03)$, fat (0.73 kg in UNR, 0.60 in RES+MPG, $0.65 \mathrm{~kg}$ in RES groups \pm 0.05$)$, and lactose $(0.79 \mathrm{~kg}$ in UNR,
$0.72 \mathrm{~kg}$ in RES+MPG, $0.71 \mathrm{~kg}$ in RES groups \pm 0.05 ) yields during the first 12 wk postpartum were greater $(P<0.04)$ in the UNR group than in the other groups (Figure 3). At the end of the experimental period (12 wk), mean milksolids ( $1.30 \mathrm{~kg}$ in UNR, $1.09 \mathrm{~kg}$ in RES+MPG, $1.09 \mathrm{~kg}$ in RES groups \pm 0.04$)$, protein $(0.57$ $\mathrm{kg}$ in UNR, $0.51 \mathrm{~kg}$ in RES+MPG, $0.50 \mathrm{~kg}$ in RES \pm $0.04)$, fat $(0.73 \mathrm{~kg}$ in UNR, $0.58 \mathrm{~kg}$ in RES+MPG, 0.59 $\mathrm{kg}$ in RES groups \pm 0.05$)$ and lactose $(0.83 \mathrm{~kg}$ in UNR, $0.75 \mathrm{~kg}$ in RES+MPG, $0.75 \mathrm{~kg}$ in RES groups \pm 0.05 ) yields were greater $(P<0.01)$ in the UNR group compared with the RES and RES+MPG groups.

\section{Hormonal and Metabolic Measurements}

Feed restriction alone affected plasma concentrations of insulin, with lower concentrations in the RES group $(P=0.027)$ compared with the UNR group (Figure 4a). There were no differences in plasma concentrations of insulin between the RES+MPG group and the UNR or the RES groups.

The effect of feed restriction was observed on IGF-I concentrations and also a treatment by time interaction with a changing pattern through time $(P=0.009)$ because concentrations in the UNR group increased relative to the RES and RES+MPG groups.

There were no differences in GH concentrations among the groups. There was a significant interaction $(P=0.038)$ between treatments over time, caused by the increase in concentrations of GH in the RES group only.

Plasma concentrations of NEFA were greater $(P<$ 0.001) in the RES group compared with the RES+MPG and UNR groups (Figure 4b). There was also a treat- 
a)

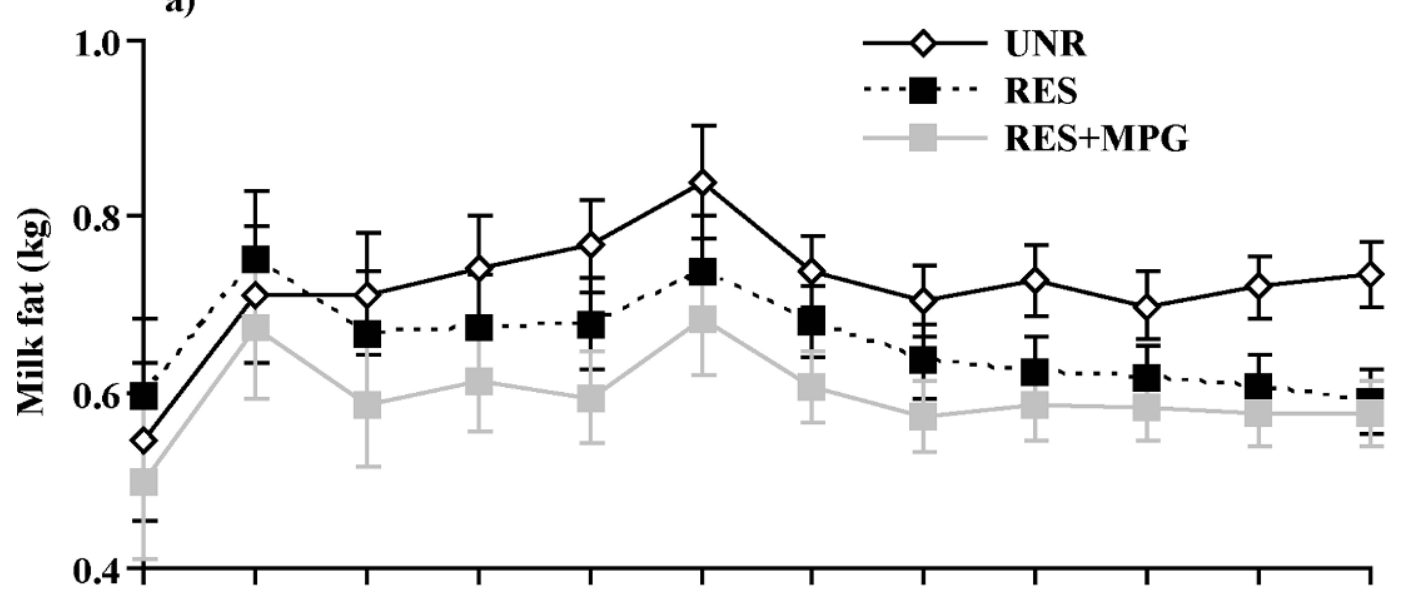

b)

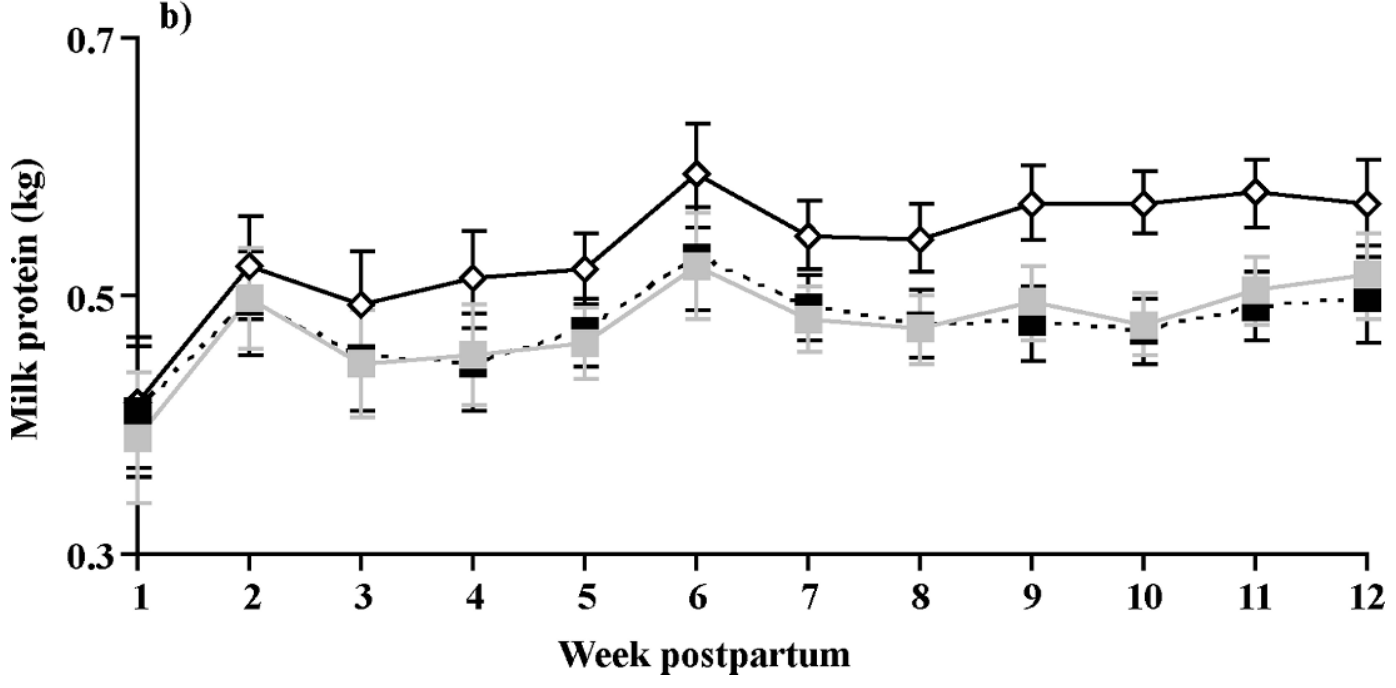

Figure 3. Mean (a) milk fat and (b) protein yields during the first 12 wk postpartum. Heifers had unrestricted (UNR) or restricted access to pasture (RES) or restricted access to pasture and supplemented with monopropylene glycol (RES+MPG). Error bar represents the maximum standard error of the difference.

ment by time interaction on NEFA concentrations that was negligble at the end of the treatment period $(P=$ $0.036)$.

As expected, there was a feed restriction effect $(P=$ 0.038 ) on glucose concentrations with lower concentrations in the RES group compared with the RES+MPG and UNR groups, and this difference decreased with time $(P=0.014$; Figure $4 \mathrm{c})$.

A treatment effect on leptin concentrations was observed $(P=0.041)$, with the UNR group having greater concentrations of leptin than the RES group $(P=0.013)$. No differences were observed between the RES+MPG and the UNR or the RES groups (Figure $4 \mathrm{~d}$ ).

\section{Effect of Propylene Glycol on Insulin and Metabolites}

During the MPG challenge, insulin concentrations increased in the RES+MPG group $(P<0.01)$ in response to the MPG administration. Glucose concentrations remained constant in the RES+MPG group for $240 \mathrm{~min}$, while glucose concentrations decreased slowly for 240 min in the RES group. Plasma concentrations of NEFA decreased in both groups and returned to prechallenge level by $240 \mathrm{~min}$ (Figure 5).

\section{Liver mRNA}

Relative GHR1A, GHRtotal, and IGF-I mRNA expressions decreased postpartum $(P<0.05)$ with no effect of feed restriction or MPG supplementation, or interaction between time and treatment (Figure 6).

\section{DISCUSSION}

Restricted feeding postpartum with or without MPG supplementation did not increase the interval from 

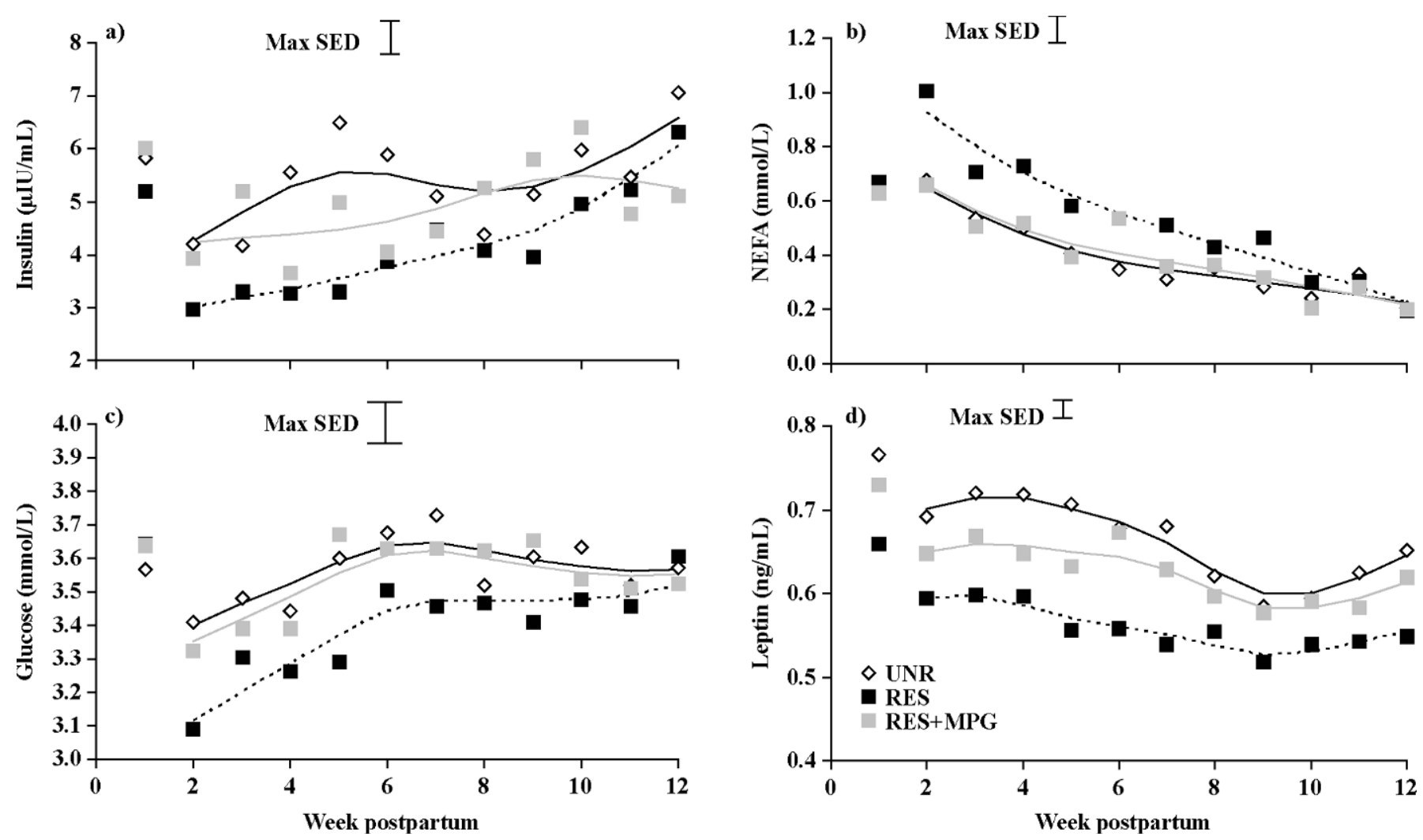

Figure 4. Mean plasma (a) insulin, (b) NEFA, (c) glucose, and (d) leptin concentrations during the first 12 wk postpartum. Heifers had unrestricted (UNR) or restricted access to pasture (RES) or restricted access to pasture and supplemented with monopropylene glycol (RES+MPG). Error bar represents the maximum standard error of the difference.

calving to first ovulation but decreased milk production in heifers calving in optimal body condition (BCS of 5.5 on a 1 to 10 scale) in a seasonal pasture based system. This is in agreement with other studies (Burke et al., 2005; Chagas et al., 2006; Burke and Roche, 2007). A previous study using heifers with low BCS (BCS of 4.0) at calving demonstrated the importance of the level of feeding prepartum and BCS at calving for the initiation of ovulation postpartum (Chagas et al., 2007). In this study the PPAI was around $62( \pm 4 \mathrm{~d})$ for heifers calving in optimal BCS (6.3) and 83 ( $\pm 3 \mathrm{~d}$ ) for heifers calving in low BCS (Chagas et al., 2007). The mechanism by which body condition influences PPAI is still unclear especially regarding the role of insulin and glucose on the resumption of ovarian activity in postpartum dairy cattle.

In this study, pasture-restricted heifers lost more BW after calving than the UNR group without an effect on BCS as previously observed in mature cows fed a restricted diet after calving (Burke and Roche, 2007). There are several reasons why BW were affected by the feed restriction without an associated decrease in BCS. First, there are limitations to the body scoring tech- nique in cows because it fails to account for changes in internal fat and protein reserves that are mobilized in early lactation. Second, changes in BCS after calving are influenced by genotype and environment interactions that determine the extent to which body reserves are partitioned toward milk production (Roche et al., 2006). Holstein-Friesian heifers used in this study were selected to produce milk in a New Zealand pasturebased system. These heifers would not normally mobilize body reserves to the detriment of health and fertility as has been observed with North American genotype cows in a pasture system (Roche et al., 2006). The age of the cows could also explain the lack of changes in BCS in this study. Multiparous high-producing cows ( $\geq 4 \mathrm{yr}$ old) have a fast rise to peak milk production and a sharp decrease in BCS after calving and these changes are less severe in primiparous cows (e.g., 2-yr-old cows used in this study).

In the RES groups, MPG did not decrease PPAI when the same drenching regimen with MPG has been shown to decrease PPAI in heifers calving in low body condition (BCS of 4.1; Chagas et al., 2007). In the present study, all heifers calved in optimal body condition for 

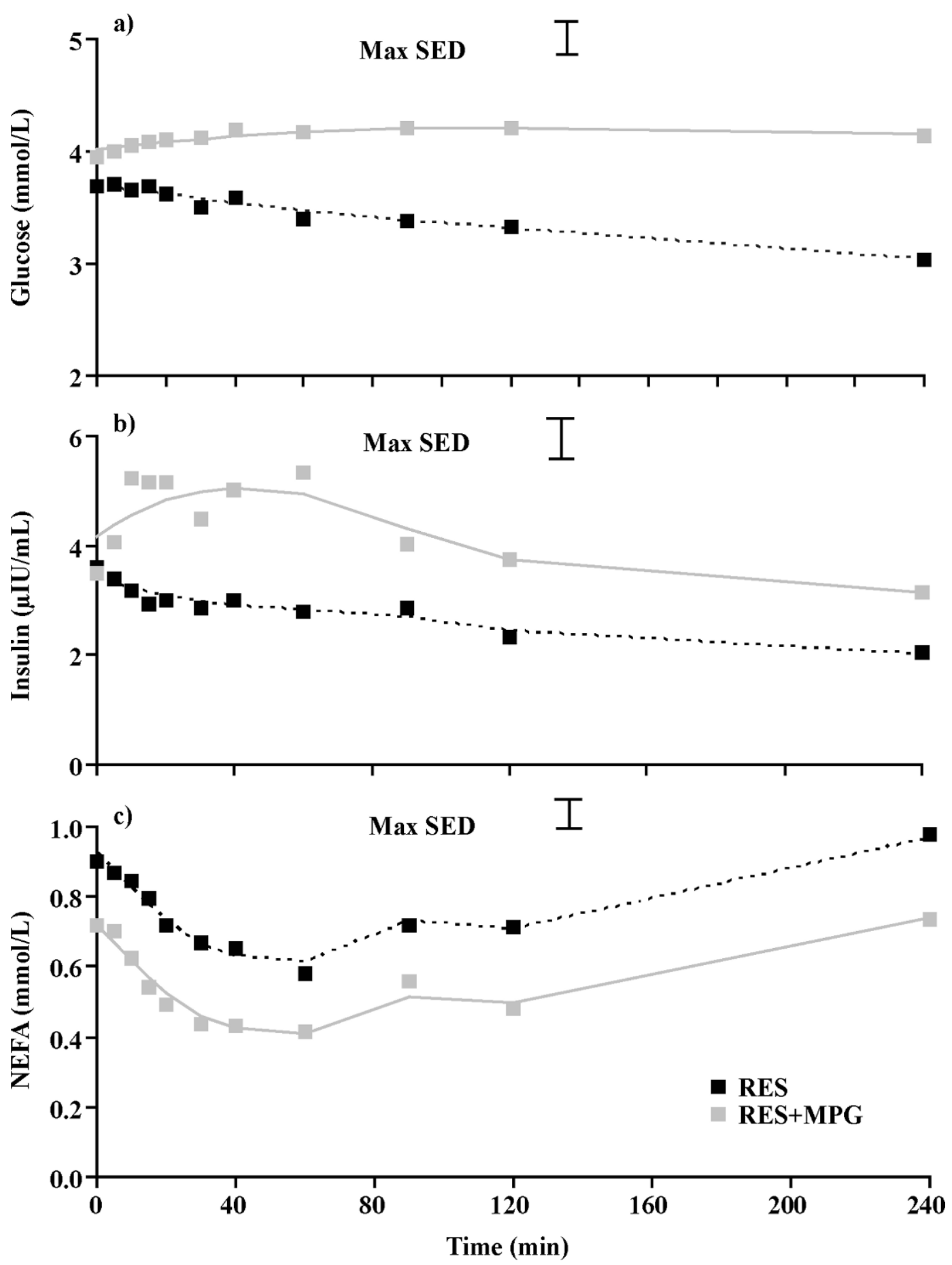

Figure 5. Mean plasma (a) glucose, (b) insulin, and (c) NEFA concentrations during a monopropylene glycol (MPG) challenge at wk 2 after calving. Heifers were fed restricted access to pasture (RES) only or restricted access to pasture and supplemented with monopropylene glycol (RES+MPG). Error bar represents the maximum standard error of the difference.

the New Zealand dairy pasture system (BCS of 5.0; Burke and Roche, 2007), and as such were considered to have adequate levels of energy reserves at calving. This is greater than that of the cows used in our previ- ous study (BSC of 4.1 at calving; Chagas et al., 2007). The comparison of the 2 studies suggests that a low (e.g., 4.1) BCS at calving is essential for MPG to improve PPAI; however, this hypothesis needs be tested in a 

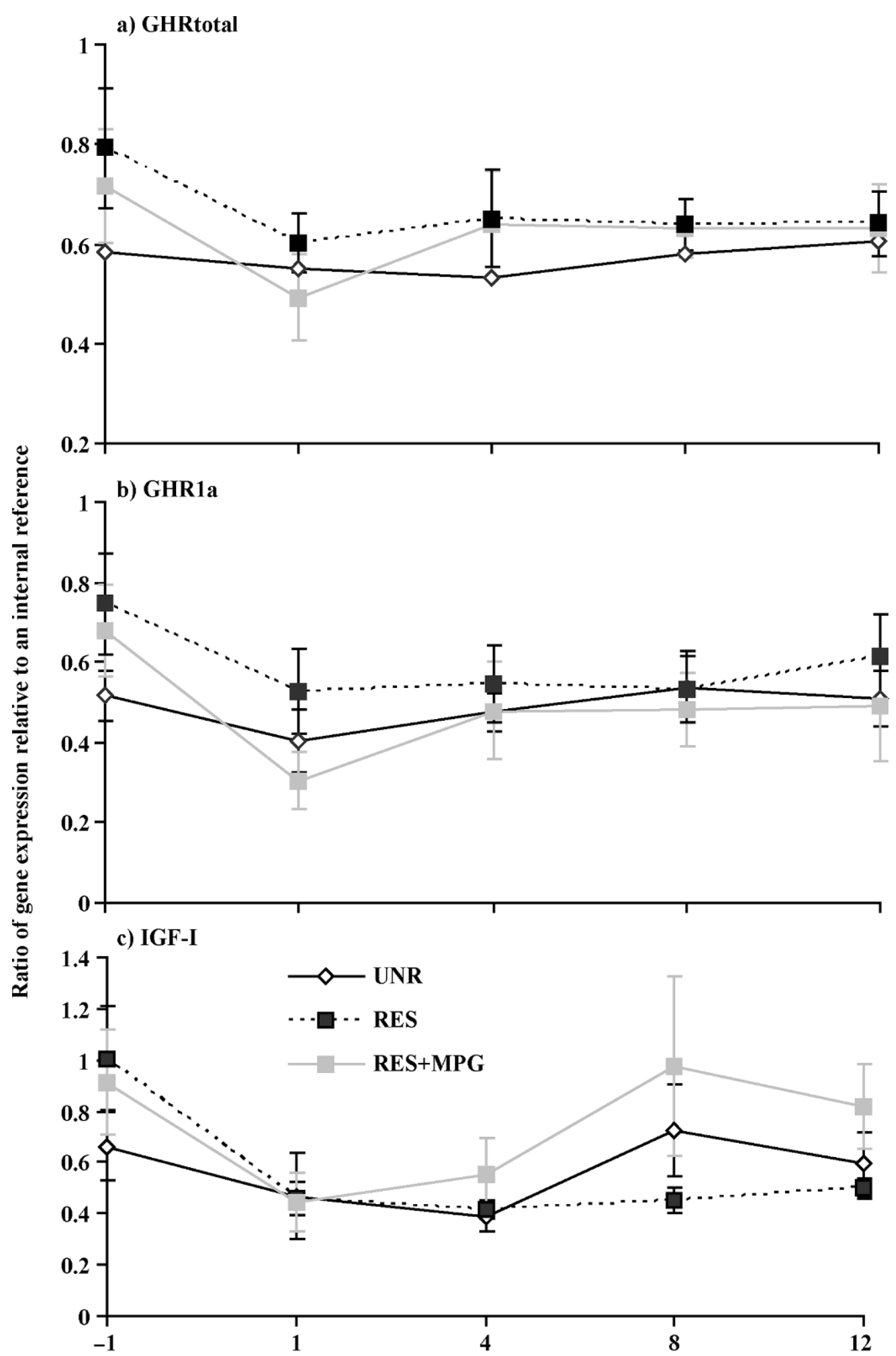

Week postpartum

Figure 6. Relative mRNA expression of (a) total growth hormone receptor (GHRtotal), (b) growth hormone receptor 1A (GHR1a), and (c) IGF-I in hepatic tissue. The gene expression is relative to an internal reference sample (pool of subset of samples). Heifers were fed unrestricted access to pasture (UNR) or restricted access to pasture (RES) only or restricted access to pasture and supplemented with monopropylene glycol (RES+MPG). Error bars represent the standard error of the difference. 
single experiment. Alternatively, in the current study, the level of underfeeding after calving was not sufficient to affect the interval to the onset of first estrus, despite the heifers with a restricted access to pasture being energetically challenged as demonstrated by lower milk production than the UNR heifers. The UNR heifers appeared to have used the extra energy available from feeding to produce more milk, suggesting that 1) the level of energy was sufficient for the reproductive axis to be stimulated in the feed-restricted heifers or 2) the partitioning of energy was preferentially directed toward the reproductive axis in all 3 groups of heifers, regardless of their level of nutrient intake during the postpartum period. Overall, the results illustrate the relationship between changes in energy balance and the activity of the reproductive axis (Butler et al., 1981).

The feed restriction, with or without MPG, did not induce a reduction in the relative expression of GHRtotal, GHR1a, or IGF-I mRNA in the liver. However, plasma concentrations of GH increased and circulating IGF-I levels decreased in the RES group, which is consistent with GH resistance (Kim et al., 2006). During feed restriction without MPG, the lack of change in liver sensitivity to GH or IGF-I could have overridden any negative effect of the decrease in both insulin and leptin induced by our feed restriction, which is correlated to the length of PPAI (Canfield and Butler, 1991; Kadokawa et al., 2000; Gong et al., 2002; Chagas et al., 2006). It has to be noted that MPG associated with feed restriction did not change any of the hormonal systems measured or the liver sensitivity to GH or IGF-I. However, treatment with MPG increased glucose and reduced NEFA concentrations, as described previously (Grummer et al., 1994; Miyoshi et al., 2001; Chagas et al., 2007), an occurrence that has been associated with resumption of ovarian cyclicity in postpartum cows (Diskin et al., 2003). Our results illustrate the complex interactions between nutrients and hormonal systems and the sensitivity to these hormones in the link between metabolic status and reproductive activity (Blache et al., 2007).

\section{CONCLUSIONS}

In this study, the effects of restricted access to pasture postpartum and benefits of MPG supplementation on PPAI in heifers were not observed. The restricted feeding levels postpartum had a negative impact on milk production postpartum, and monopropylene glycol supplementation postpartum did not prevent this decrease in milk production. The feed restriction may not have been severe enough to affect PPAI and no benefits of MPG supplementation to pasture-restricted heifers were observed. Overall, our results suggest that the level of postpartum nutrition, or supplementation of energy, is not a strong driver of the resumption of ovarian cyclicity in dairy heifers calving in optimal BCS.

\section{ACKNOWLEDGMENTS}

The authors thank Victoria Miller, Virginia Salveragio, John Williams, Bruce Sugar, and the staff at the DairyNZ Lye farm. Margaret Blackberry of The University of Western Australia provided technical assistance and the Dairy Cattle Fertility Science Group assisted with sample collection. John Bass provided constructive criticism of the manuscript and Barbara Dow gave statistical advice. Agri-Feeds' support is also acknowledged. This research was funded by the Foundation for Research, Science and Technology, New Zealand, and by the New Zealand Dairy Farmers, through the Dairy InSight research fund.

\section{REFERENCES}

Bauman, D. E., and W. B. Currie. 1980. Partitioning of nutrients during pregnancy and lactation: A review of mechanisms involving homeostasis and homeorhesis. J. Dairy Sci. 63:1514-1529.

Bertics, S. J., R. R. Grummer, C. Cadorniga-Valino, and E. E. Stoddart. 1992. Effects of prepartum dry matter intake on liver triglyceride concentration in early lactation. J. Dairy Sci. 75:1914-1922.

Blache, D., L. M. Chagas, M. A. Blackberry, P. E. Vercoe, and G. B. Martin. 2000. Metabolic factors affecting the reproductive axis in male sheep. J. Reprod. Fertil. 140:1-11.

Blache, D., L. M. Chagas, and G. B. Martin. 2007. Nutritional inputs into the reproductive neuroendocrine control system-A multidimensional perspective. Soc. Reprod. Fertil. Suppl. 64:123-139.

Breier, B. H., and P. D. Gluckman. 1991. The regulation of postnatal growth: Pathways and function of the somatotrophic axis. Livest. Prod. Sci. 27:77-94.

Burke, C. R., and J. R. Roche. 2007. Effect of level of pasture feeding during the periparturient period on postpartum anovulatory intervals in pasture-grazed dairy cows. J. Dairy Sci. 90:4304-4312.

Burke, C. R., J. R. Roche, P. W. Aspin, J. M. Lee, and V. K. Taufa. 2005. Effect of pre- and postpartum pasture feeding intakes on postpartum anoestrous intervals in dairy cows. Proc. N.Z. Soc. Anim. Prod. 65:221-224.

Butler, W. R., R. W. Everett, and C. E. Coppock. 1981. The relationships between energy balance, milk production and ovulation in postpartum Holstein cows. J. Anim. Sci. 53:742-748.

Canfield, R. W., and W. R. Butler. 1991. Energy balance, first ovulation and the effects of naloxone on LH secretion in early postpartum dairy cows. J. Anim. Sci. 69:740-746.

Chagas, L. M., P. J. S. Gore, S. Meier, K. A. Macdonald, and G. A. Verkerk. 2007. Effect of monopropylene glycol on luteinizing hormone, metabolites and postpartum anovulatory intervals in dairy heifers. J. Dairy Sci. 90:1168-1175.

Chagas, L. M., F. M. Rhodes, D. Blache, P. J. S. Gore, K. A. Macdonald, and G. A. Verkerk. 2006. Precalving effects on metabolic responses and postpartum anestrus in grazing primiparous dairy cows. J. Dairy Sci. 89:1981-1989.

Chomczynski, P., and N. Sacchi. 1987. Single-step method of RNA isolation by acid guanidinium thiocyanate-phenol-chloroform extraction. Anal. Biochem. 162:156-159.

Diskin, M. G., D. R. Mackey, J. F. Roche, and J. M. Sreenan. 2003. Effects of nutrition and metabolic status on circulating hormones and ovarian follicle development in cattle. Anim. Reprod. Sci. 78:345-370. 
Downing, J. A., J. Joss, P. Connel, and R. J. Scaramuzzi. 1995. Ovulation rate and the concentration of gonadotrophic and metabolic hormones in ewes fed lupin grain. J. Reprod. Fertil. 103:137-145.

Emery, R. S., N. Burg, and L. D. Brown. 1964. Detection, occurrence and prophylactic treatment of borderline ketosis with propylene glycol feeding. J. Dairy Sci. 47:1074-1079.

Etherton, T. D., and D. E. Bauman. 1998. Biology of somatotropin in growth and lactation of domestic animals. Physiol. Rev. 78:745-761.

Formigoni, A., M. C. Cornil, A. Prandi, A. Mordenti, A. Rossi, D. Portetelle, and R. Renaville. 1996. Effect of propylene glycol supplementation around parturition on milk yield, reproduction performance and some hormonal and metabolic characteristics in dairy cows. J. Dairy Res. 63:11-24.

Gluckman, P. D., J. J. Johnson-Barrett, J. H. Butler, B. W. Edgar, and T. R. Gunn. 1983. Studies of insulin-like growth factor -I and -II by specific radioligand assays in umbilical cord blood. Clin. Endocrinol. (Oxf.) 19:405-413.

Gong, J. G., W. J. Lee, P. C. Garnsworthy, and R. Webb. 2002. Effect of dietary-induced increases in circulating insulin concentrations during the early postpartum period on reproductive function in dairy cows. Reproduction 123:419-427.

Grummer, R. R., J. C. Winkler, S. J. Bertics, and V. A. Studer. 1994. Effect of propylene glycol dosage during feed restriction on metabolites in blood of prepartum Holstein heifers. J. Dairy Sci. 77:3618-3623.

Hales, C. N., and P. J. Randle. 1963. Immunoassay of insulin with insulin-antibody precipitate. Biochem. J. 88:137-146.

Janovick-Guretzky, N. A., H. M. Dann, D. B. Carlson, M. R. Murphy, J. J. Loor, and J. K. Drackley. 2007. Housekeeping gene expression in bovine liver is affected by physiological state, feed intake, and dietary treatment. J. Dairy Sci. 90:2246-2252.

Kadokawa, H., D. Blache, Y. Yamada, and G. B. Martin. 2000. Relationships between changes in plasma concentrations of leptin before and after parturition and the timing of first post-partum ovulation in high-producing Holstein dairy cows. Reprod. Fertil. Dev. 12:405-411.

Kim, J. W., R. P. Rhoads, N. Segoale, N. B. Kristensen, D. E. Bauman, and Y. R. Boisclair. 2006. Isolation of the cDNA encoding the acid labile subunit (ALS) of the $150 \mathrm{kDa}$ IGF-binding protein complex in cattle and ALS regulation during the transition from pregnancy to lactation. J. Endocrinol. 189:583-593.
Macdonald, K. A., and J. Roche. 2004. Condition Scoring Made Easy. Condition scoring dairy herds. 1st ed. Dexcel Ltd., Hamilton, New Zealand.

McGuire, M. A., J. L. Vicini, D. E. Bauman, and J. J. Veenhuizen. 1992. Insulin-like growth factors and binding proteins in ruminants and their nutritional regulation. J. Anim. Sci. 70:29012910.

Miyoshi, S., J. L. Pate, and D. L. Palmquist. 2001. Effects of propylene glycol drenching on energy balance, plasma glucose, plasma insulin, ovarian function and conception in dairy cows. Anim. Reprod. Sci. 68:29-43.

Radcliff, R. P., B. L. McCormack, B. A. Crooker, and M. C. Lucy. 2003. Plasma hormones and expression of growth hormone receptor and insulin-like growth factor-I mRNA in hepatic tissue of periparturient dairy cows. J. Dairy Sci. 86:3920-3926.

Roche, J. R., D. P. Berry, and E. S. Kolver. 2006. Holstein-Friesian strain and feed effects on milk production, body weight, and body condition score profiles in grazing dairy cows. J. Dairy Sci. 89:3532-3543.

Roche, J. R., P. Dillon, S. Crosse, and M. Rath. 1996. The effect of closing date of pasture in autumn and turnout date in spring on sward characteristics, dry matter yield, and milk production of spring-calving dairy cows. Irish J. Agric. Food Res. 35:127-140.

Roche, J. R., P. G. Dillon, C. R. Stockdale, L. H. Baumgard, and M. J. VanBaale. 2004. Relationships among international body condition scoring systems. J. Dairy Sci. 87:3076-3079.

Roche, J. R., E. S. Kolver, and J. K. Kay. 2005. Influence of precalving feed allowance on periparturient metabolic and hormonal responses and milk production in grazing dairy cows. J. Dairy Sci. 88:677-689.

Sauer, M. J., J. A. Foulkes, A. Worsfold, and B. A. Morris. 1986. Use of progesterone 11-glucuronide-alkaline phosphatase conjugate in a sensitive microtitre-plate enzymeimmunoassay of progesterone in milk and its application to pregnancy testing in dairy cattle. J. Reprod. Fertil. 76:375-391.

Schmidt, F. H. 1961. Enzymatic determination of glucose and fructose simultaneously. Klin. Wochenschr. 39:1244-1247.

Thom, E. R., G. W. Sheath, A. M. Bryant, and N. R. Cox. 1986. Renovation of pastures containing paspalum 1. Persistence of overdrilled ryegrass and prairie grass and effect on seasonal pasture production. N.Z. J. Agric. Res. 29:575-585.

Verbyla, A. P., B. R. Cullis, M. G. Kenward, and S. J. Welham. 1999 The analysis of designed experiments and longitudinal data using smoothing splines (with discussion). Appl. Stat. 48:269-311. 